\title{
On the ecology of ciliates in riverwaters: The evaluation of water quality via ciliates and filamentous bacteria
}

\author{
Fred Stoessel \\ EAWAG/ETH, Ueberlandstraße 133, CH-8600 Dübendorf
}

Key words: Ecology; ciliates; river; water quality; sphaerotilus.

\begin{abstract}
Since sewage treatment plants are most effective in Switzerland, the micro-benthic communities in receiving running waters have changed considerably. From January 1980 to September 1981 the periphyton communities in 13 Swiss streams and rivers were monthly investigated. The $\mathrm{NH}_{\mathbf{4}}-\mathrm{N}$ concent ration in these waters varied between 0.015 and $1.0 \mathrm{mg} / 1$. Four typical communities of microorganisms were found:

In unpolluted running waters mainly small vagile ciliates were abundant; in slightly polluted waters peritricha (in the presence of bacteria) were found; in moderatly polluted waters peritricha in combination of few hymenostomata and Sphaerotilus could grow when bacteria and some degredable organic material where present; in polluted waters the well-known Spaerotilus-community (after Liebmann) could be found.

The microscopic as well as the macroscopic aspect should be considered to qualify the degree of pollution in streams and rivers.
\end{abstract}

\section{Introduction}

The 'Allgemeine Gewässerschutzverordnung' prescribes ongoing surveillance of underground and surface waters (1) and water-quality targets are outlined in article 1 of the 'Verordnung über Abwassereinleitungen' (18). The statement that conformity with waterquality guidelines be verified is much easier than fulfilling such a requirement, because fluctuations in the concentrations of dissolved substances, as well as temporal and local factors, make controls particularly difficult to carry out $(10,14)$. Over a two-year period, Jakob $(11,12)$ removed random samples from a moderately polluted river at hourly intervals. Within a single day, he detected up to 60 -fold variations in the concentration of ammonium-nitrogen and even on average, concentrations varied by a factor of 8 . This problem can be solved by using longerterm integrated sampling techniques (7). However, this raises the question of how far the values measured by such techniques, which are obviously suitable for the calculation of pollution burdens, are applicable for the evaluation of the real condition of rivers and it seems probable that only biological parameters could satisfy such a requirement. In 1971 Warren (19) commented that properly used, biological indices can give early warnings. Our conception of the relationship between society and 
water pollution as well as our knowledge of the responses of communities to environmental change determine the usefulness of such biological indices.

Thanks to the success of a major anti-pollution programme, running waters in Switzerland are presently only slightly polluted. In saprobiological terminology, they mainly fall in the categories from oligo- to $\beta$-mesosaprobic. There are very few entirely or partially $\alpha$-mesosaprobic rivers and, with the exception of a few heavily polluted stretches of streams, the polysaprobic category is also largely absent.

As early as 1974/75, we attempted to use ecological criteria in the study of rivers (15). However, the necessary chemical and biological data bases were inadequate for reliable evaluation. Therefore, in order to improve the data base for ecological evaluation, specific long-term observations at 17 sites on selected rivers were undertaken in $1980 / 81$.

This paper deals with the approximate structure of "Aufwuchs" with different kinds of loadings, but specific species distributions are not emphasized. For the experimental biologist this requires less detailed work than would have been needed if precise taxonomic distinctions had been made. Nevertheless, the classification of the water-quality of running waters demands knowledge of both appropriate sampling methods and about the character and hydrography of the water course under investigation (17).

\section{Method}

\subsection{The Sampling Sites}

The 17 sites lie on 16 different rivers and streams throughout Switzerland. Their geographical position has been described by Frutiger 1985 (9). All sites were visited at approximately monthly intervals from January 1980 to September 1981. Four of the sites are not mentioned in this report for the following reasons: three of these are located on streams formed from glacial melt, which are cloudy during the summer; the fourth is a very small mountain stream which, in many respects, cannot be compared with the other, larger rivers. In the field studies, both macro- and microinvertebrates were examined simultaneously, thus, the sampling sites were spread over the whole of Switzerland in order to cover diverse zoogeographical regions, even though protozoa are less affected by geographical location than macroinvertebrates.

\subsection{Sampling of ciliate and filamentous bacteria}

As in previous investigations (16), the material for the study of protozoan fauna was taken from growth on stones. The sampling procedure and the quantification of the sample is extensively described by Stössel 1986 (17). Microscopic examination was performed on site immediately after sampling, to avoid changes resulting from lack of food, predation, oxygen loss or temperature changes in the sampling vessels. The presence of macroscopically visible peritricha colonies and the abundance of Spaerotilus natans were record. 
The peritrichous ciliates were recorded under the following categories:

a) no visible colonies

b) colonies discernible as fine traces

c) colonies present as thick, readily visible films.

Table 1. Assessment criteria for Sphaerotilus abundance. Since growth is strongly influenced by high water levels, only results from samples taken at least 14 days after the last "high water" were included in this study, thus ensuring that all growth had occurred in the absence of mechanical disturbance.

\begin{tabular}{ll}
\hline Abundance & Description \\
0 & no Sphaerotilus visible, even microscopically, in samples of growth on stones. \\
1 & isolated bacterial strands in microscopic preparation \\
2 & a small number of bacterial strands in microscopic preparation \\
3 & frequent Sphaerotilus strands in microscopic preparation \\
4 & numerous Sphaerotilus strands in microscopic preparation, Sphaerotilus also visi- \\
5 & ble beneath stones with naked eye \\
\hline
\end{tabular}

\subsection{Chemical Reference Parameters}

In order to characterize the local conditions, chemical parameters were measured in random water samples. However, few of these parameters exert any direct influence on ciliates, therefore, they will be referred to as reference parameters. A sample was taken at the beginning and the end of each biological sampling period, and transported to the laboratory in isolated vessels. From the more than thirty measured parameters, ammonium-nitrogen and total-phosphorus were selected for this report. The measured values are depicted in figures $1 \mathrm{a}$ and $1 \mathrm{~b}$. Although the study deliberately included heavily polluted rivers, the variation of the median values is very small. Therefore, since the values of the individual concentrations (particularly $\mathrm{NH}_{4}-\mathrm{N}$ ) were very scattered and their distribution rarely fitted any of the common distribution functions, the median values were used for further analysis.

\section{Results}

\subsection{The dependence of peritrichous ciliate incidence on chemical pollution}

Data evaluation is based on the classifications given in the 'Empfehlungen über die Untersuchung der schweizerischen Oberflächengewässer' (7), which defines pollution classes from unpolluted to heavily polluted for a number of parameters. In figures $2 \mathrm{a}$ to $2 \mathrm{c}$, the mean value of the total-phosphorous in the filtrate is plotted against the number of peritrichous ciliate species present. To take into account possible seasonal variations in conditions, the results from summer (1st April to 31st October) and winter are presented separately in figures $2 \mathrm{a}$ and $2 \mathrm{~b}$. With two exceptions in both half years, the number of species increases with increasing phosphorus pollution. The first exception, the Bünz (BU), is a small river in the Alpine foothills, heavily polluted by the effluent from villages and a large abattoir (Qmean ca. $2 \mathrm{~m}^{3} / \mathrm{s}$ ). 

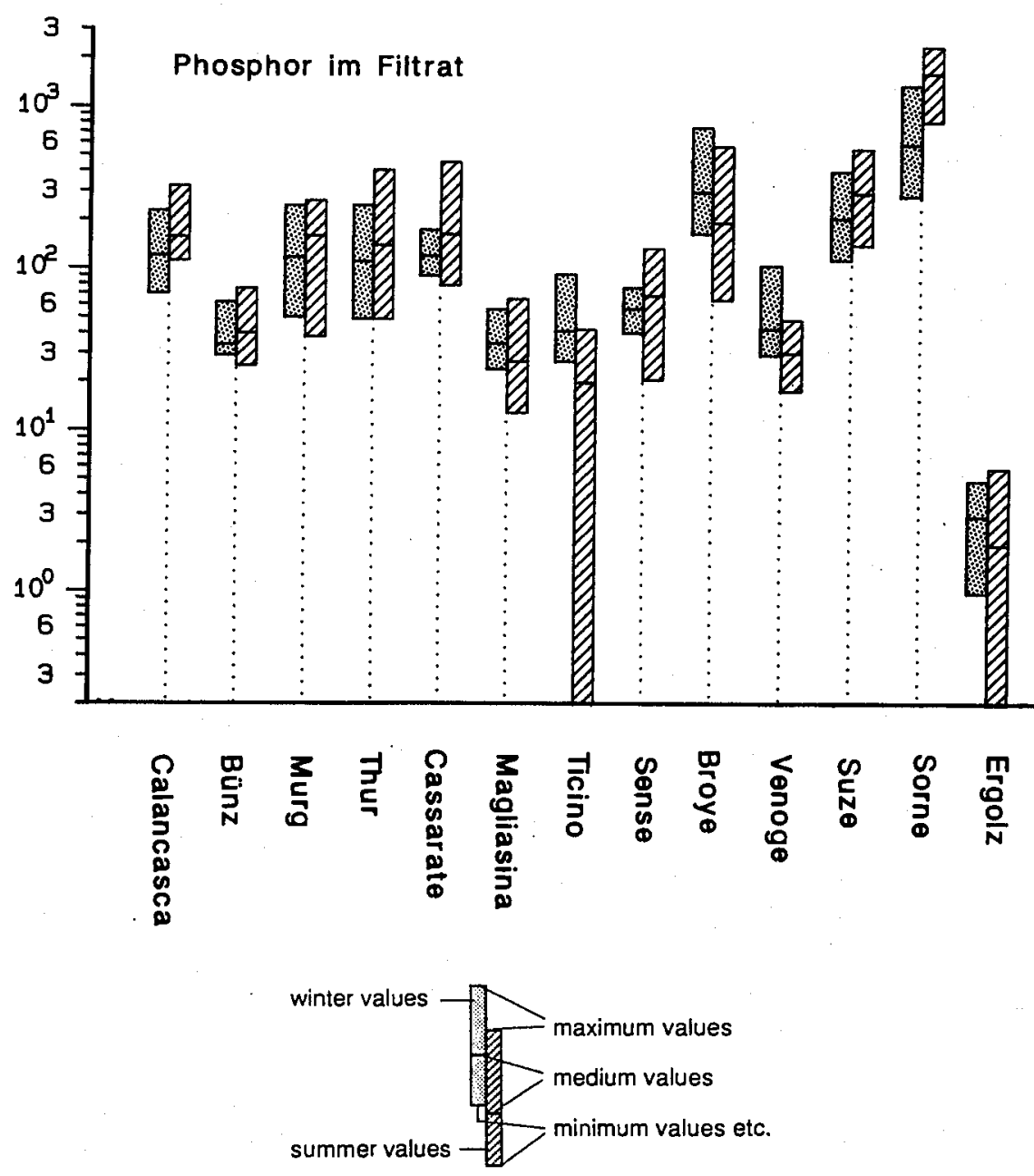

Figure $1 \mathrm{a}$. Maximum and minimum values in $\mathrm{mg} / \mathrm{l}$ of the reference parameter total-phosphorus in the filtrate and $\mathrm{NH}_{4}-\mathrm{N}$. Average number of values per sampling site used for the calculations: in winter 12

(Bünz 8), and in summer 24 (Bünz 11).

In the Bünz, the peritrichous diversity was small throughout the period of the investigation. The Cassarate (CA), the second exception, is also heavily polluted with untreated water at the sampling site. The peritrichous diversity during the summer was twice that of the winter period. This may be caused by the often much higher flow rate in summer (16); the consequent dilution of the untreated effluent allowing a greater species diversity. Without this large dilution, the concentration of sewage water would increase significantly over the summer period, because of the large increase in the number of visitors to the near-by holiday resorts. In the Ergolz (ER), the problem is different: here during the summer, up to 17 different species of peri- 


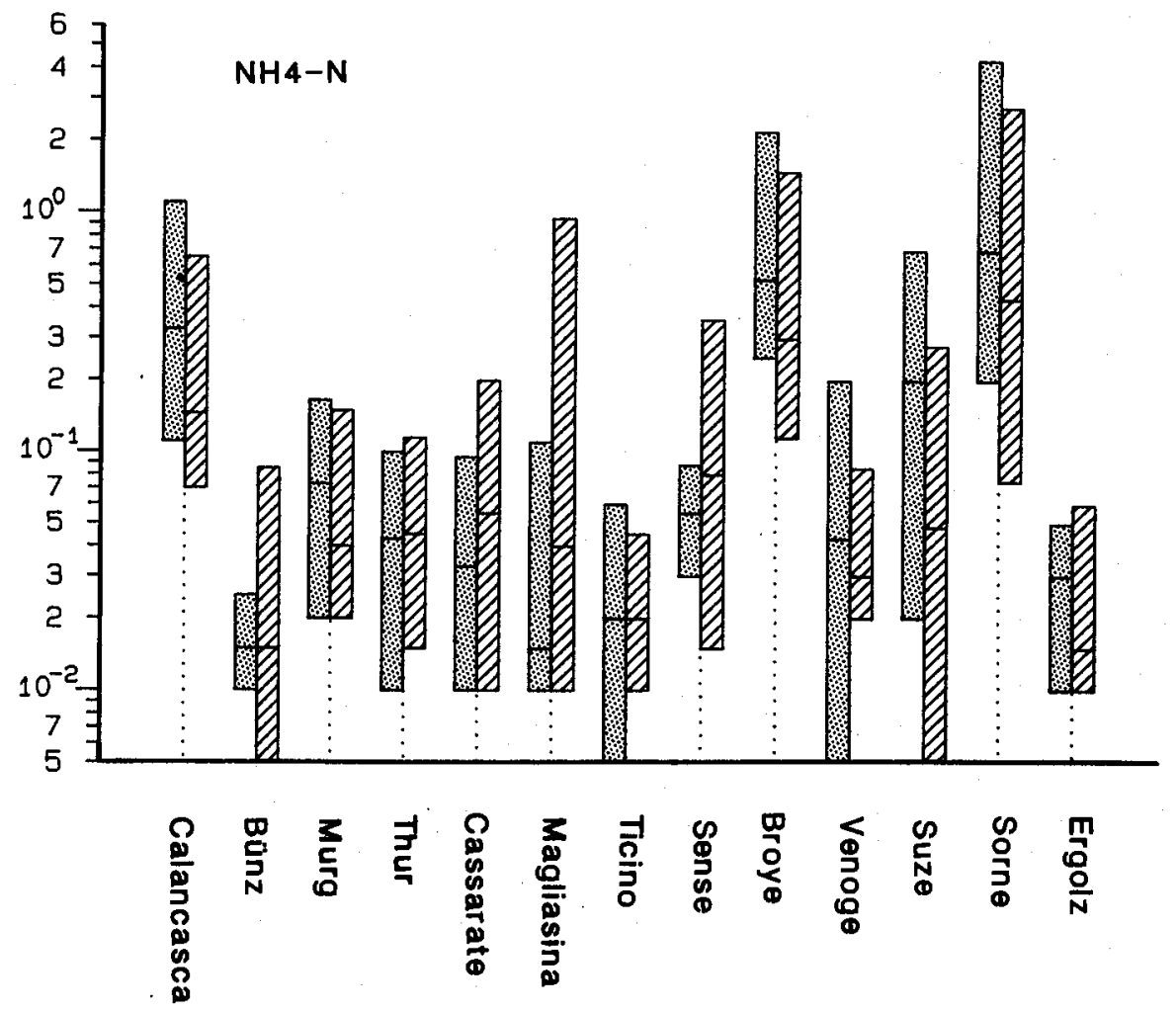

Figure 1b. Maximum and minimum values in $\mathrm{mg} / \mathrm{l}$ of the reference parameter $\mathrm{NH}_{4}-\mathrm{N}$. For further information see figure $1 \mathrm{a}$.

trichous ciliates were found simultaneously. The median concentrations of the chemical reference parameters, however, remained close to their winter levels, even though the volume of effluent approximately halved during the summer period: with the exception of $\mathrm{NH}_{4}-\mathrm{N}$ (figure $1 \mathrm{a}$ ) whose concentration sank to a median of a little over $1 \mathrm{mg} / \mathrm{l}$.

If the total-phosphorus values over the whole sampling period are plotted against the maximum number of species detected, then here too a reduction in diversity above $300 \mathrm{mg} / 1$ phosphorus is apparent. Although no correlation is evident in figure 3, trends present in figures $2 \mathrm{a}$ and $2 \mathrm{c}$ are confirmed. Again, the Cassarate and the Bünz are on the right hand side, suggesting less diversity than the level of pollution would imply. According to the guidelines laid down in the 'Empfehlungen über die Untersuchung schweizerischer Oberflächengewässer' (7), the overall range of values for total phosphorus in the filtrate and ammonium-nitrogen for both these rivers imply that they would fall into the 'heavily polluted' category. 
PERITRICHA

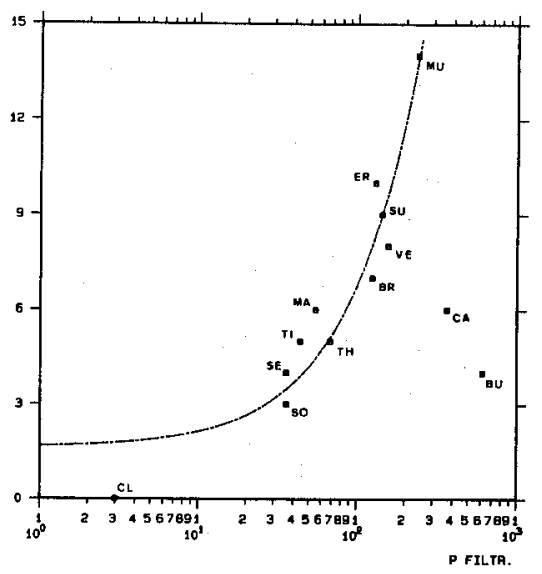

$\begin{array}{lccc}\text { Cutve } & A & B & .22 \\ Y M A+(B m X) & 1.63393 & .512831 E-1 & .001864\end{array}$
PERITRICHA

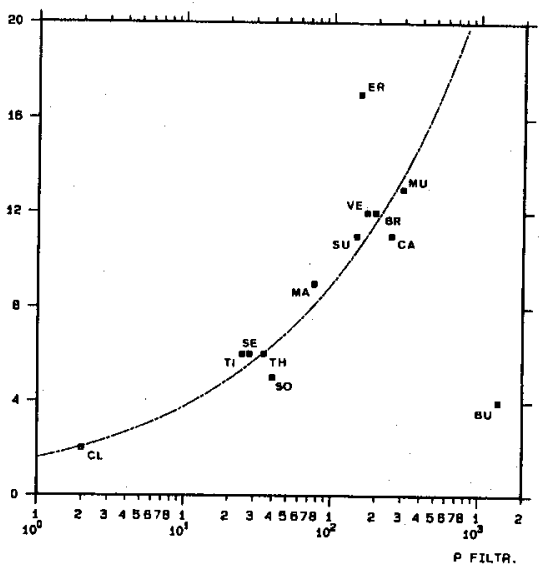

Curve $\quad$ a $\quad r^{-2}$

$Y$ YAE $\left(X^{*} B\right) \quad$ A. $89724 \quad .375087$

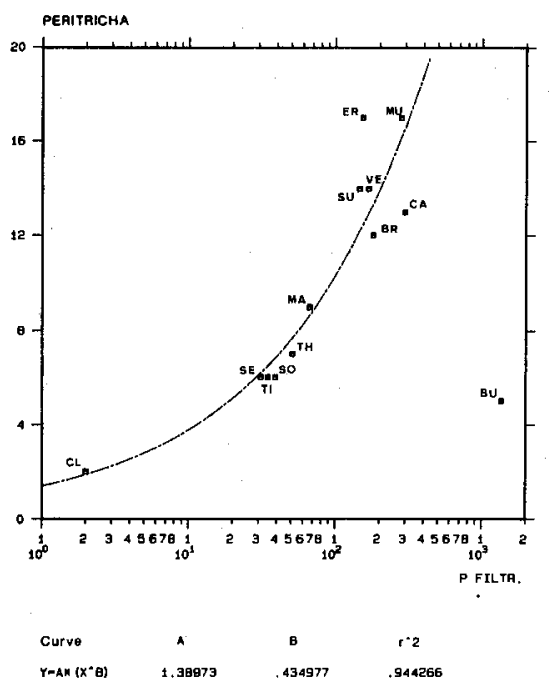

Figures $2 \mathrm{a}-\mathrm{c}$. Maximum number of species detected aginst the median values of the reference parameter phosphorus in the filtrate. $2 \mathrm{a}$, summer; $2 \mathrm{~b}$, winter; $2 \mathrm{c}$, Jan. $80-$ Sept. 81 . The following were not included in the correlation calculation: in $2 \mathrm{a}, \mathrm{ER}$ and $\mathrm{BU} ;$ in $2 \mathrm{~b}, \mathrm{CA}$ and $\mathrm{BU}$; and in $2 \mathrm{c}, \mathrm{BU}$. In these and the following figures, the rivers' names are abbreviated to their first two letters (except for the Calancasca $=\mathrm{CA}$ ). For the unabbreviated forms, see figures $1 \mathrm{a}$ and $\mathrm{b}$. Figure $3: \mathrm{NH}_{4}-\mathrm{N}$ concentration against the number of peritrichous species. 


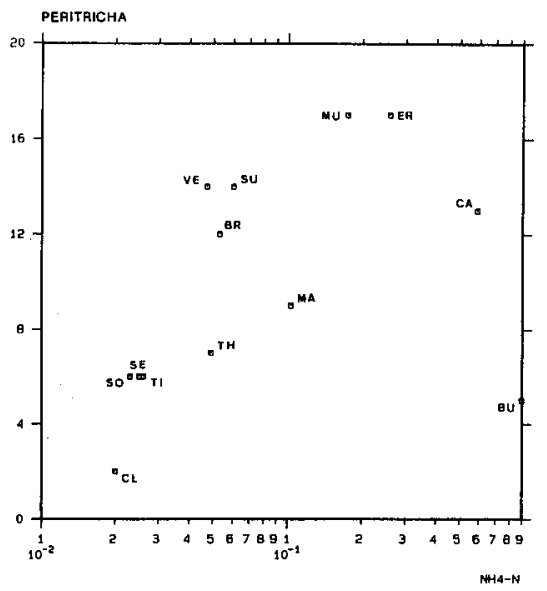

Figure 3. $\mathrm{NH}_{4}-\mathrm{N}$ concentration against the number of peritrichous species.

\subsection{The dependence of peritrichous ciliate abundance on chemical pollution}

Although precise sampling and quantification of peritrichous ciliates is not possible and the concentrations of chemicals in any single biological sample are coincidental, certain trends are apparent. Figures $4 \mathrm{a}$ and $4 \mathrm{~b}$ present the peritrichous ciliate frequency in the context of the median values of the pollutant parameters totalphosphorus in the filtrate and ammonium-nitrogen. Both the number of different species and their frequency rise with increasing pollution, only to fall again at high concentrations. (This was first established in a microscopic study of growth at 380 sites during the years 1974/75 (Stössel, unpublished). The macroscopic detection limit for peritrichous strands is a density of ca. 500 individuals per 20 microscope fields of view at 100x magnification. Above 1500 individuals, the peritrichous colonies generally appear as thick, fur-like »cushions': Within this category, further division into thinner colonies and very dense and thick fur-like colonies is possible. On the whole, in the Maglisina (MA), Venoge (VE) and Murg (MU), no thick peritrichous growth was present, whereas, in the Ergolz (ER), Broye (BR), and above all the Cassarate (CA), dense peritrichous ciliate populations were visible: at this last site, the colonies were predominantly thick and fur-like. In figure $4 \mathrm{a}$, the Sorne (SO) lies outside the main scatter of points. This stream, in Jura canton, goes underground for a few kilometers before re-emerging a short distance above the sampling site. Apart from the neighbouring woods and a few fields, there are no significant food sources for bacterivorous filter feeders in this reach of the stream. The ammonium-nitrogen burden in particular is very low (see figure $1 \mathrm{a}$ ): the occasional somewhat elevated values could come from the rather small area of agricultural land. 

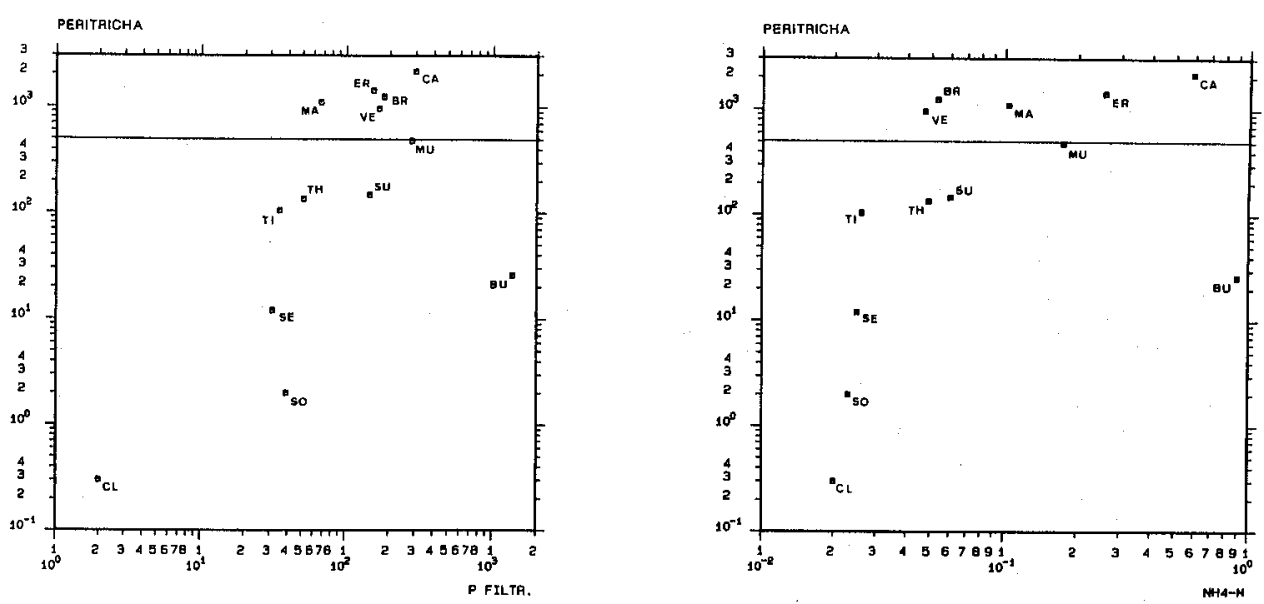

Figures $4 \mathrm{a}$ and $4 \mathrm{~b}$ : peritrichous ciliate frequency plotted against the median values of a) totalphosphorus in the filtrate, and b) the $\mathrm{NH}_{4}-\mathrm{N}$ concentration.

The horizontal line in the uppermost third of the diagrams corresponds to the macroscopic detection limit mentioned in the text. The colonies from the sampling sites lying above this line were generally visible to the naked eye.

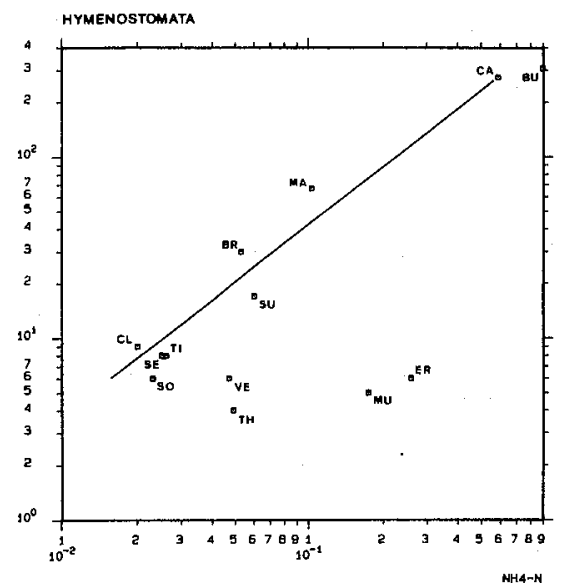

Figure 5: Hymenostomous ciliate frequency against the $\mathrm{NH}_{4}-\mathrm{N}$ concentration. The straight line drawn by hand is not a correlation curve, but serves to clarify comments in the made text.

\subsection{Relationship between hymenostomous ciliates and chemical pollution}

Figure 5 shows that the hymnestomous ciliate frequency increases with increasing ammonium-nitrogen concentration, although four exceptions should be mentioned: over a large portion of their courses, the Murg (MU) and Ergolz (ER) flow through 

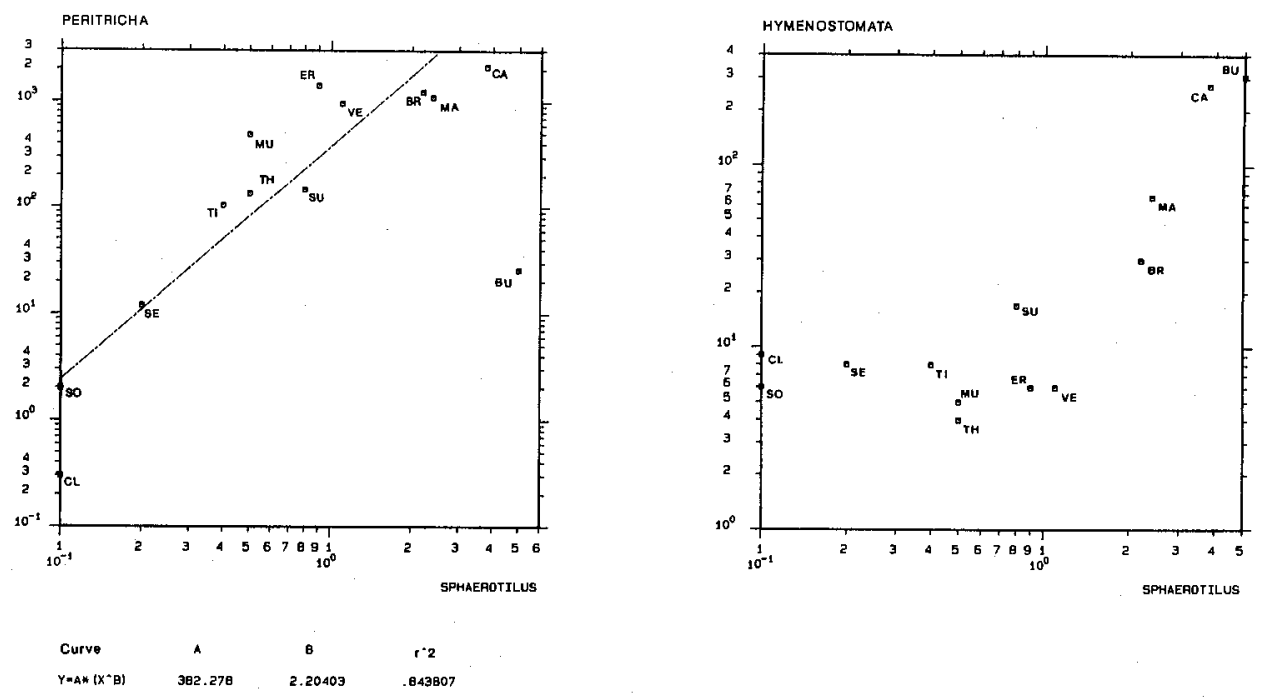

Figures $6 \mathrm{a}$ and $6 \mathrm{~b}$ : Plots of the Sphaerotilus abundance against $a$ ) the peritrichous ciliate frequency and $b$ ) the hymenostomous ciliate frequency. The Bünz (BU) was not included in the calculation of the regression function for fig. $6 \mathrm{a}$.

agricultural land, and receive a relatively high input of treated sewage water, which explains their, in a Swiss context, above average ammonium-nitrogen content. However, since their biodegradable organic content is low, bacteria production is low. Thus, hymenostomic ciliate growth is limited, since as vagile filter feeders they rely on a high density of growing bacteria (see section 3.4). Similar conditions apply to the Thur (TH) and Venoge (VE), but the flow rate of the Thur is approximately twice that of the Murg, and because of the low population density of its drainage area, the Venoge has a lower sewage input than the Ergolz.

\subsection{Ciliate frequency and Sphaerotilus growth}

The dependence of Sphaerotilus natans growth on the amount of organic material available in the water has often been described, and is uncontested $(3,4,5,14)$. It is less clear, however, whether there is a relationship between peritrichous ciliate frequency and Sphaerotilus. Since there is a relationship between organic pollution and peritrichous ciliate frequency (see section 3.2), it is to be expected that this parallel dependence would manifest itself as a regression. Indeed, in figure 6 a there is good agreement between Sphaerotilus abundance and peritricha frequency. With the exception of the Bünz, the logarithmic pairs of values fit a linear regression ( $\mathrm{r} 2=$ 0.844). The exceptional case of the heavily polluted Bünz will not be discussed further in this paper, however, a possible explanation follows for the three most markedly deviating rivers the Murg, Ergolz and Cassarate: in the cases of the Murg and 
Ergolz, the only inputs upstream of the sampling point are treated sewage and agricultural run-off. Bacterial drift is sufficient to support dense peritrichous growth, although the substrate concentration is inadequate for a large Sphaerotilus population. Upstream of the sampling point, the Cassarate receives a considerable input of untreated domestic sewage, containing both adequate substrate for Sphaerotilus and free bacteria for peritrichous ciliates, thus leading to the highest peritrichous density of all the sampling sites. Figure $6 \mathrm{~b}$ supports the contention that the higher hymnestomous ciliate frequencies require the presence of sufficient quantities of growing bacteria, and a dependence is only apparent where the pollution-burden is high.

\subsection{The effect of increasing pollution on the relative abundance of peritrichous and hymenostomous ciliates}

We have shown above that at low hymenostomous ciliate frequencies $(<20)$ there is no correlation between frequency and organic pollution, the scatter covering almost the whole of the pollutant-burden range. This is less true for peritrichous ciliates, although frequency drops off at very high pollution levels. Figure 7 presents the peritrichous ciliate frequencies in ascending order, with the exception of the heavily polluted Bünz whose values are at the right hand side, as a histogram, with the frequency and abundance respectively of Hymenostoma and Sphaerotilus superposed.

The peritrichous ciliate frequency does not correlate perfectly with the concentrations of degradable organic material as represented by the Sphaerotilus abundance. This is clear in the cases of the Ergolz and the Murg (fig. 6a), where the peritrichous ciliates are abundant, whilst hymenostomous ciliate are not. This may be a consequence of the elevated bacteria density but low concentrations of degradable organic material. The Venoge presents a similar picture. Certainly, it should be borne in mind that long self-cleaning stretches to sewage treatment plants have similar effects. The peritrichous fauna of the Bünz is completely different: the low frequency detected is most probably the result of competition for living space between Sphaerotilus natans and the peritricha, predominantly Carchesium polypinum. The rapid growth of the sewage bacteria, which stifle all competition, and whose tufts are kept short by the current, leaves little space in which peritricha can grow. The very low peritrichous density (figs. $4 \mathrm{a}, \mathrm{b}, 6 \mathrm{a}$ and 7 ) is, at the most, analogous to that of the rivers whose organic pollution is low. The overall Ciliate community corresponds reasonably closely to the Sphaerotilus community described by Liebmann (13).

The histograms for hymenostomous ciliates and Sphaerotilus show a clear similarity. Sphaerotilus is capable of rapid growth because of its rapid metabolism, though only in the presence of sufficient degradable organic pollution: thus, it is most dense in the immediate vicinity of a pollutant source. At high frequencies, hymenostomous ciliates show a positive correlation with pollutant parameters (fig. 5). Hence, at higher pollution levels, predictions may be based on Hymenostomata and Sphaerotilus frequencies combined.

A number of pollution categories may be derived from figure 7 . Thus, the results for 

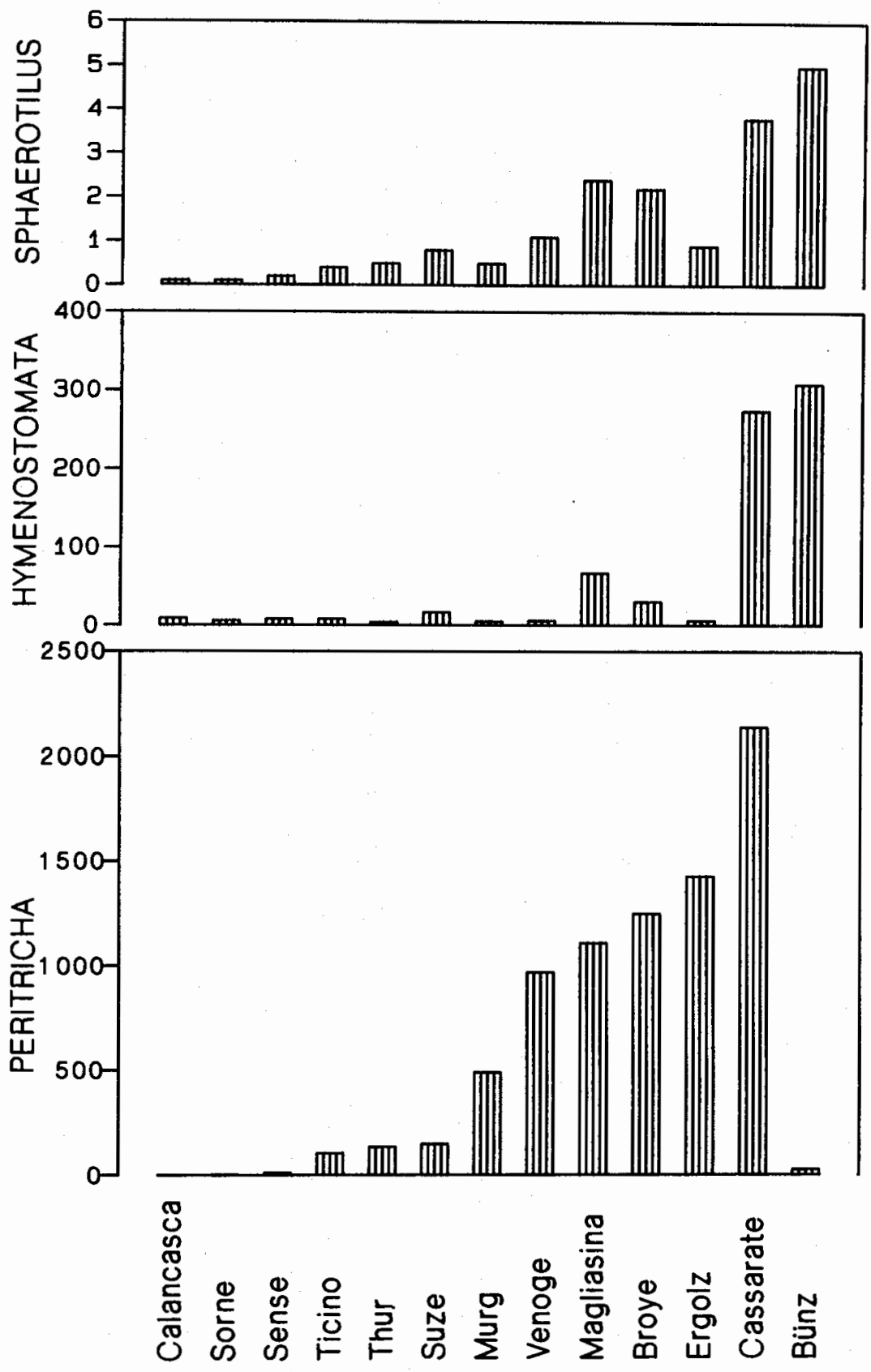

Figure 7. Histograms of the peritrichous and hymenostomous ciliate frequencies, and the Sphaerotilus abundance. 
the Calancasca, Sorne, Sense, Ticino, Thur and Suze point to low organic pollution, whereas those for the Murg, Venoge and Ergolz through the bacteria, reveal significant pollution. Whether the bacteria originated in sewage works or proliferated during the self-cleaning process, is of no importance in this context. The incidence of hymenostomous ciliates and Sphaerotilus in both these categories is low. A non-negligible level of degradable organic pollution was present in the Magliasina, Broye and Cassarate, and the bacterial burden was sufficient to support a high density of Peritricha. The Bünz exemplified another pollution-burden category. characterized by an enourmous reduction in the peritrichous density compared to the Cassarate: though additional sampling at suitable, less-polluted sites or sites on longer selfcleaning stretches might yield different results. In the third pollution-burden category, hymnenostomous ciliates are present at more frequent, reaching high densities in the Cassarate: the trend of the Sphaerotilus abundance is also clearly upward. In the final pollution-burden category, represented here by the Bünz, both the hymenostomous ciliates and Sphaerotilus levels are very high. The pollution communities here emphasized, naturally do not correspond to any rigid ecological boundary entities, but rather to fluid boundaries.

\section{Application of the Results: Discussion}

Figure 7 shows that, in the presence of diverse groups of pollutants, the microorganisms form typical communities, which can readily be differentiated. Four types of pollution predominated in the rivers studied: the respective pollution communities are summarized in table 2 and described more fully below.

The first community corresponds to the group of unpolluted and negligibly polluted rivers. Neither ciliates nor Sphaerotilus natans dominate, and never exceed low frequencies. Ciliate communities consist mainly of small, barely visible vagile forms. The second community, which could be defined as the 'Peritrichous group' is distinguished by a peritrichous population with several species, the aggregates ranging in size from macroscopically invisible to readily visible. The hymenostomous ciliates are somewhat more abundant than in the first category, yet the vagile forms are very infrequent, if present at all. Sphaerotilus natans is microscopically generally readily detected, however, macroscopically at best visible as very small, individual tufts beneath stones (8). Rivers showing such an incidence of Sphaerotilus mainly carry treated effluent, or the sampling site lies on a stretch featuring efficient self-cleaning. Above all, sewage treatment plants with inadequate retention of bacterial aggregates, or which release sludge from the secondary clarifier can give rise to this community in the receiving rivers.

The third group is characterized by an elevated abundance of Sphaerotilus natans and hymenostomous ciliates, as a consequence of higher concentrations of degradable organic material. Under these conditions, Sphaerotilus may also be present on the upper, light-facing side of stones. Peritrichous ciliates too, may reach high frequencies, appearing as fine, but dense, fur-like coatings.

Characterized of the fourth group is a sudden decrase in the peritricha frequency, although the conditions remain optimal for the growth of Sphaerotilus natans. The 
hymenostomous ciliates also attained their maximum abundance, including the larger forms Paramecium sp. and Colpidium sp., which were found at high frequencies. It should be mentioned that the only heavily polluted sampling site, where anaerobic conditions extended over the whole breadth of the river leading to the formation of iron sulphide and the covering of the river bed in black mud, proved to be an exception. Even in the third pollution category, such iron sulphide formation could only be detected in small, isolated areas under stones.

One consequence of the fact that $81 \%$ of the Swiss population are served by sewage treatment plants (as of 1.1. 83, Lit. (2)), is that currently the vast majority of Swiss rivers and streams fall into the society categories 1 and 2, and the Sphaerotilus communities are in continual decline. The decrease in organic pollution resulting from the measures taken to protect rivers could lead one to the conclusion that bacteria from effluent and ciliates are not well-suited to the description of lightly- and negligibly-polluted rivers. This certainly not the case, since biological assessment of rivers relies on sensitive, quickly-reacting organisms. Indeed, they are all the more necessary since investigations of macroinvertebrate societies have shown that, in the least polluted categories, macroinvertebrate community are far more susceptible to hydrographic parameters than to the bacteria and degradable organic material carried in the water. In such situations, ciliates and Sphaerotilus natans allow a prediction to be made, since they are less influenced by hydrographic conditions. Thus, for example, the same ciliates are present in both swiftand slow-flowing rivers, but in the former simply less abundant at any particular pollution level.

\section{REFERENCES}

1 Allgemeine Gewässerschutzverordnung vom 19. Juni 1972 (Stand am 1. Juli 1981). Syst. Sammlung des Bundesrechtes, Ziff. 814.201.

2 Bundesamt für Umweltschutz Gewässerschutzstatistik. Schriftenreihe Umweltschutz, Nr. 46 (1985).

3 Eichenberger, E., 1967, Ökologische Untersuchungen an Modellfließgewässern: I. Die jahreszeitliche Verteilung der bestandesbildenden pflanzlichen Organismen bei verschiedener Abwasserbelastung. Schweiz. Z. Hydrol. 29: 1-31.

4 Eichenberger, E., 1967, Ökologische Untersuchungen an Modellfließgewässern: II. Jahreszeitliche Veränderungen der Biomassebildung bei verschiedenen Abwasserbelastungen. Schweiz. Z. Hydrol. 29: 32-52.

5 Eichenberger, E., 1972, OKkologische Untersuchungen an Modellfließgewässern: III. Die jahreszeitlichen Veränderungen im Verhältnis von heterotropher zu phototropher Biomasse bei verschiedenen Abwasserbelastungen. Schweiz. Z. Hydrol. 34: 155-172.

6 Eichenberger, E., 1972, Ökologische Untersuchungen an Modellfließgewässern: IV. Auswirkungen der Selbstreinigung auf die Biomassebildung in einem Abwassergradienten. Schweiz. Z. Hydrol. 34: 173-189.

7 Eidgenössisches Departement des Innern, 1982, Empfehlungen über die Untersuchung der schweizerischen Oberflächengewässer.

8 Favre, J., 1975, Inhibition de la lumière visible et UV-proche à forte intensité. Dissertation ETH Nr. 5411.

9 Frutiger, A., 1985, The production quotient PQ: A new approach for quality determination of slightly to moderately polluted running waters. Arch. Hydrobiol. 104: 513-526.

10 Güttinger, H., 1982, Zusammenhänge zwischen physikalischen und chemischen Faktoren und Makroinvertebraten in Fließgewässern. Dissertation ETH Nr. 6952. 
11 Jakob A., 1983, Tagesperiodik ausgewählter chemischer und physikalischer Parameter in einem Fließgewässer (La Suze, Vallon St. Imier). Lizentiatsarbeit Zool. Inst. Univ. Bern.

12 Jakob, A. und Tschumi, P.-A., 1988, Tagesschwankungen chemischer und physikalischer Faktoren in einem Fließgewässer (Schüss, Berner Jura). Arch. Hydrobiol. 113: 607-620.

13 Liebmann, H., 1951, Handbuch der Frischwasser- und Abwasserbiologie. R. Oldenbourg, München, $539 \mathrm{p}$.

14 Meier, W., 1980, Untersuchungen über die biologische Wirkung periodischer Belastungsschwankungen in Fließgewässern. Dissertation ETH Nr. 6546.

15 Perret, P., 1977, Zustand der schweizerischen Fließgewässer in den Jahren 1974/75. Eidgenössisches Amt für Umweltschutz.

16 Stössel, F., 1979, Autökologische Analyse der in schweizerischen Fließgewässern häufig vorkommenden Ciliatenarten und ihre Eignung als Bioindikatoren. Schweiz. Z. Hydrobiol. 41: 113-140.

17 Stössel, F., 1987, Effect of the coefficients of discharge on ciliate populations of a running water contaminated by municipal wastewater. Arch. f. Hydrobiol. 108: 483-497.

18 Verordnung über Abwassereinleitungen vom 8.12. 1975 (Stand am 1. Oktober 1980). Syst. Sammlung des Bundesrecht, Ziff. 814.225.21, Bern.

19 Warren, C. E., 1971, Biology and Water Pollution Control. W. B. Saunders Company, Philadelphia, London, Toronto, $434 \mathrm{p}$.

Received 23 August 1988;

accepted 17 January 1989. 